Check for updates

Cite this: RSC Adv., 2018, 8, 24827

\title{
Enhanced photocatalytic and antibacterial activity of plasma-reduced silver nanoparticles $\dagger$
}

\author{
L. Chandana, ${ }^{a}$ P. Ghosal, ${ }^{\text {b }}$ T. Shashidhar ${ }^{c}$ and Ch. Subrahmanyam (D) *a
}

A non-thermal atmospheric pressure plasma jet has been used for the green synthesis of highly dispersed colloidal silver nanoparticles. The reducing species such as hydrogen radicals and hydrated electrons are identified, and the change in the solution $\mathrm{pH}$ is studied during AgNP formation. The structural properties and size of the plasma-reduced silver nanoparticles are characterized via X-ray diffraction, ultraviolet-visible spectroscopy, fluorescence spectroscopy and transmission electron microscopy. The size of the colloidal AgNPs is tuned by adjusting the initial concentration of $\mathrm{AgNO}_{3}$. The effect of terephthalic acid, a hydroxyl radical scavenger, on the reduction of $\mathrm{Ag}^{+}$ion is studied. The typical catalytic activity data indicate the better performance of the plasma-reduced colloidal Ag nanoparticles than that obtained from the chemical reduction method. The antibacterial activity of the plasma-reduced Ag nanoparticles also shows a better performance than that of the chemically reduced AgNPs, highlighting the potential of the plasma reduction approach for the synthesis of metal nanoparticles, which are stable even after 30 days without a stabilizing agent. Additionally, the effects of hydroxyl scavengers (isopropyl alcohol) and Fenton's reagent ( $\mathrm{Fe}^{2+}$ salt) on CV degradation are studied.

Received 9th May 2018

Accepted 23rd June 2018

DOI: $10.1039 / \mathrm{c} 8 \mathrm{ra03961e}$

rsc.li/rsc-advances into the visible region by incorporating metal nanoparticles $(\mathrm{Ag} /$ $\mathrm{Au} / \mathrm{Mn} / \mathrm{Cr}$ ) into the $\mathrm{TiO}_{2}$ matrix or $\mathrm{Au} / \mathrm{Ag}$ NPs supported on $\mathrm{TiO}_{2}$, which can improve its visible light response. ${ }^{12-14}$ A large number of preparation methods have been reported for the synthesis of noble nanoparticles such as laser ablation, electrochemical synthesis, microwave irradiation, radiolysis, solvothermal synthesis, chemical reduction methods and glow discharge plasma. ${ }^{15-19}$ Among these methods, the chemical reduction route is simple and less time consuming. In the chemical reduction process, reducing agents such as hydrazine hydrate $\left(\mathrm{N}_{2} \mathrm{H}_{4}\right)$ and sodium borohydride $\left(\mathrm{NaBH}_{4}\right)$ are used to reduce the metal precursors, and the resulting nanoparticles are stabilized with sodium dodecyl sulfate (SDS) and $N$-vinylpyrrolidone. ${ }^{\mathbf{1 8 , 2 0}}$ Picosecond laser ablation and ultrasonic irradiation have been tested for the synthesis of AgNPs; ${ }^{15,21}$ however, these methods have specific limitations due to the need for highly sophisticated instruments, and their reducing agents are harmful to the environment. Accordingly, the synthesis of stable silver nanoparticles without the use of capping agents is highly desirable.

Non-thermal plasma reduction is a green, fast, economic and facile synthesis method for colloidal AgNPs in the absence of stabilizers at ambient conditions. ${ }^{22}$ Electrical discharge in water may alter physical and chemical properties and may create a reactive environment such as shock waves, high electric fields, UV radiation and in particular chemically reactive species such as hydroxyl radicals $\left({ }^{\circ} \mathrm{OH}\right)$, hydrogen radicals $\left({ }^{\circ} \mathrm{H}\right)$ and hydrated electrons $\left(\mathrm{e}_{\mathrm{aq}}{ }^{-}\right) \cdot{ }^{23}$ In this scenario, ${ }^{\circ} \mathrm{H}$ and $\mathrm{e}_{\mathrm{aq}}{ }^{-}$act as reducing agents, which can reduce $\mathrm{Ag}^{+}$to $\mathrm{Ag}$. Furthermore, the highly energetic electrons play a vital role in protecting the
${ }^{a}$ Department of Chemistry, Indian Institute of Technology, Kandi-502285, Hyderabad, Telangana, India. E-mail: csubbu@iith.ac.in

${ }^{b}$ Defence Metallurgical Research Laboratory (DMRL), Kanchanbagh, Hyderabad 500058, India

${ }^{c}$ Department of Civil Engineering, Indian Institute of Technology, Kandi-502285, Hyderabad, Telangana, India

$\dagger$ Electronic supplementary information (ESI) available. See DOI: 10.1039/c8ra03961e 
formed colloidal AgNPs from aggregation. Hydrogen $\left(\mathrm{H}_{2}\right)$ plasmas have been used successfully to reduce metal ions due to the production of strong reducing species such as ${ }^{\cdot} \mathrm{H}^{\mathbf{2 4 , 2 5}}$ However, an atmospheric pressure plasma jet (APPJ) operating under argon atmosphere is the most efficient and economical process.

Herein, the synthesis of AgNPs has been carried out with an atmospheric pressure plasma jet under ambient conditions; AgNPs are synthesized without the use of either a reducing agent or a stabilizer. The size of AgNPs in the colloidal solution is tuned by changing the reaction conditions. The formation of AgNPs is confirmed by various techniques such as structural (XRD and TEM) and optical (UV-Vis and fluorescence) spectroscopies. Additionally, the photocatalytic activity and antibacterial activity of the plasma-reduced AgNPs (Ag-P) are tested, and the results are compared with those of chemically reduced AgNPs (Ag-C).

\section{Experimental}

\subsection{Experimental setup}

A schematic of the experimental setup and details are given elsewhere. ${ }^{26}$ Briefly, plasma was created by applying high voltage between a stainless steel inner electrode (high voltage electrode) and stainless steel mesh outer electrode (ground electrode). A high voltage probe was connected to the inner electrode to measure the applied voltage $(16 \mathrm{kV})$, and the voltage $(V)$-charge $(Q)$ waveforms were recorded using an oscilloscope (Tektronix TDS 2014B). The applied voltage $(V)$ was plotted against the charge $(Q)$ to obtain a Lissajous figure, and its area was multiplied by the frequency to give the power dissipated in the discharge. ${ }^{23,27}$ The power dissipated in the discharge was around $0.9 \mathrm{~W}$ at an applied voltage of $16 \mathrm{kV}$.

\subsection{Reagents and methods}

Silver nitrate $\left(\mathrm{AgNO}_{3}\right)$, sodium borohydride $\left(\mathrm{NaBH}_{4}\right)$, monochloroacetic acid $\left(\mathrm{ClCH}_{2} \mathrm{COOH}\right)$, titanium dioxide $\left(\mathrm{TiO}_{2}\right)$, crystal violet, terephthalic acid (TA), 2-hydroxy terephthalic acid (HTA), hydrogen peroxide $\left(\mathrm{H}_{2} \mathrm{O}_{2}\right)$, sulfuric acid $\left(\mathrm{H}_{2} \mathrm{SO}_{4}\right)$, potassium nitrate $\left(\mathrm{KNO}_{3}\right)$, sodium hydroxide $(\mathrm{NaOH})$, isopropyl alcohol, and ferrous chloride $\left(\mathrm{FeCl}_{2}\right)$ were purchased from Merck. An Aalborg mass flow controller (MFC) was used to adjust the gas flow rate at $300 \mathrm{sccm}$. The hydrated electrons $\left(\mathrm{e}_{\mathrm{aq}}{ }^{-}\right.$) formed during the discharge process were identified using Goodman's method..$^{23}$ For this, $1 \mathrm{mM}$ of monochloroacetic acid was used as the $\mathrm{e}_{\mathrm{aq}}{ }^{-}$scavenger, where $\mathrm{Cl}^{-}$reacts with $\mathrm{e}_{\mathrm{aq}}{ }^{-}$to give $\mathrm{Cl}^{-}$ions. The chloride ions formed during the discharge process were analyzed by ion chromatography (IC) on a DIONEX ICS-2100 using $24 \mathrm{~mA}$ current, eluent ( $25 \mathrm{mM}$ of $\mathrm{KOH}$ ) flow rate of 0.38 $\mathrm{mL} \min ^{-1}$ and $10 \mu \mathrm{L}$ of sample, and the column temperature was maintained at $30{ }^{\circ} \mathrm{C}$ during the analysis. An emission spectrometer (Princeton Instrument Action SpectraPro ${ }^{\circledR}$ SP2300) was used to identify the active species formed at the gas-liquid interface. For this, an optical fiber probe was positioned close to the flask to obtain the emission spectrum of the discharge species. A grating with a resolution of $500 \mathrm{~nm}$ at $600 \mathrm{~g}$ $\mathrm{mm}^{-1}$ was used, and the diameters of the optical sensor and optical fiber were $11 \mathrm{~mm}$ and $3.36 \mathrm{~mm}$, respectively. Plasma discharge was carried out under an argon atmosphere at a constant flow rate of $300 \mathrm{sccm}$.

Twenty $\mathrm{mL}$ of $\mathrm{AgNO}_{3}$ solution (1-3 mM) was placed in a beaker, and the plasma jet was placed approximately $3 \mathrm{~mm}$ above from the sample surface. The plasma reduction time was varied in between 5 and $15 \mathrm{~min}$. The $\mathrm{AgNO}_{3}$ solutions with different concentrations (1-3 mM) were labeled as S1, S2 and S3, respectively. Metal-impregnated $\mathrm{TiO}_{2}$ nanocomposites (Ag$\mathrm{TiO}_{2}$ ) were synthesized via the wet impregnation method. $\mathrm{TiO}_{2}$ ( $\sim 250 \mathrm{mg}$ ) was mixed with $25 \mathrm{~mL}$ of deionized water (DI) by adding an appropriate amount (0.5-2 wt\%) of AgNPs, and the resulting solution was stirred overnight, washed repeatedly with DI water, and then dried at $100{ }^{\circ} \mathrm{C} .{ }^{13}$ In the chemical method, AgNPs were prepared using $\mathrm{NaBH}_{4}$, as previously reported. ${ }^{28}$ Solutions of $2.38 \times 10^{-3} \mathrm{M} \mathrm{NaBH}_{4}$ and $1.32 \times 10^{-3} \mathrm{M} \mathrm{AgNO}_{3}$ were prepared separately. To $40 \mathrm{~mL}$ of the $\mathrm{NaBH}_{4}$ solution, 2, 4, 6 and $8 \mathrm{~mL}$ of the $\mathrm{AgNO}_{3}$ solutions were added under stirring to give a yellow colored solution. The first two solutions $(1.20 \times$ $\left.10^{-4} \mathrm{M}\right)$ were stable, whereas with the further addition of $\mathrm{AgNO}_{3}$, the solutions became unstable; after $1 \mathrm{~h}$, the solutions started to become turbid and grey.

For photocatalytic degradation, crystal violet (CV) was used as a model dye, and the photocatalytic experiments were performed under sunlight. To achieve adsorption-desorption equilibrium, the dye-containing solution along with the catalyst was placed in the dark for $30 \mathrm{~min}$ before exposure to the sunlight. The concentration after equilibrium was considered as the initial concentration $\left(20 \mathrm{mg} \mathrm{L}^{-1}\right)$. The average temperature during the experiment was found to be around $30{ }^{\circ} \mathrm{C}$ (Hyderabad: $17^{\circ} 38^{\prime} \mathrm{N}, 78^{\circ} 48^{\prime} \mathrm{E}$; date: 5 th January 2018 ). A small amount of aliquot was collected every $20 \mathrm{~min}$ and centrifuged at $5000 \mathrm{rpm}$ for $5 \mathrm{~min}$ to obtain uncontaminated supernatant. An ultraviolet-visible (UV-Vis) spectrophotometer was used to measure the concentration of dye present in the supernatant at different time intervals. The antibacterial and photocatalytic activities of three different AgNPs (S1, S2 and S3) were tested, and the results were compared with those of chemically reduced AgNPs. The plasma-reduced AgNPs and chemically reduced AgNPs are labeled as Ag-P and Ag-C, respectively.

For bacterial inactivation studies, a standard wild-type commercially available Escherichia coli DH5alpha strain was used, and similar results were found with $E$. coli BL21 and E. coli $\mathrm{K}-12$. A loop full of bacterial cells was inoculated into $100 \mathrm{~mL}$ of freshly prepared nutrient broth and then incubated to the exponential phase for $16 \mathrm{~h}$ at $37{ }^{\circ} \mathrm{C}$ with a constant stirring rate of $200 \mathrm{rpm}$. The bacterial cells were grown to $\sim 3.0$ OD at $600 \mathrm{~nm}$, harvested by centrifugation (6000 rpm) for $5 \mathrm{~min}$ and then suspended in sterilized deionized water (DI). The bacterial (E. coli) concentration was monitored using optical density (OD) at $600 \mathrm{~nm}$ at regular time intervals. To maintain the bacterial concentration relatively constant from one experiment to another, the bacterial suspension was maintained at a constant $\mathrm{OD}_{600}$ value of 0.1 .

The long-lived $\mathrm{H}_{2} \mathrm{O}_{2}$ species formed during photocatalysis were identified using titanium sulfate, which formed the yellow 
colored pertitanic acid and showed a maximum absorbance at 420 nm (T90+ UV-Vis spectrometer, PG 94 Instruments Ltd., India). Anhydrous titanium dioxide $(0.5 \mathrm{~g})$ was added to $50 \mathrm{~mL}$ of sulfuric acid, and this solution was heated to $150{ }^{\circ} \mathrm{C}$ in a sand bath for $15 \mathrm{~h}$ to obtain the titanium sulfate reagent; the solution was diluted and filtered through $0.45 \mu \mathrm{m}$ filter paper. The shortlived ${ }^{\circ} \mathrm{OH}$ species were quantified by the chemical dosimetry method, where terephthalic acid (TA) reacts with ${ }^{\circ} \mathrm{OH}$ to form 2hydroxy terephthalic acid (HTA), which is a fluorescent compound. A solution containing $2 \mathrm{mM}$ of TA, $5 \mathrm{mM}$ of $\mathrm{NaOH}$, and $50 \mathrm{mg}$ of $1 \mathrm{wt} \% \mathrm{Ag}(\mathrm{P})-\mathrm{TiO}_{2}$ catalyst $(50 \mathrm{~mL})$ was irradiated with sunlight up to $120 \mathrm{~min}$. During fluorescence spectroscopy, TA and HTA molecules in the solution were irradiated by UV light with an excitation wavelength of $310 \mathrm{~nm}$, and only HTA showed an emission at $425 \mathrm{~nm}$. The extent of mineralization was confirmed using a TOC-VCPH (Shimadzu, Japan) analyzer.

\subsection{Characterization techniques}

Various types of analytical tools were used to characterize the plasma-reduced AgNPs. A T90+ UV-Vis spectrometer (PG Instruments Ltd., India) was used to study the surface plasmon resonance (SPR) of AgNPs and to determine the concentration of $\mathrm{CV}$ present in the solution. A Horiba fluoromax-4 fluorescence spectrometer was used to study the fluorescence emission spectra of AgNPs. X-ray diffraction (XRD) was used to study the crystallinity of the Ag nanoparticles. Diffraction patterns were recorded using $\mathrm{Cu} \mathrm{K} \alpha$ radiation $(1.5418 \AA)$ with an Ni filter in the $2 \theta$ range of $5-50^{\circ}$. XRD patterns were obtained with a step size of $0.0167^{\circ}$ and a scan rate of $0.0301^{\circ} \mathrm{s}^{-1}$ on a PANalytical X'pert PRO powder X-ray diffractometer. The morphology of products was analyzed via transmission electron microscopy (TEM-TECNAI-G2 EDS model).

\section{Results and discussion}

\subsection{Identification of reducing species}

Fig. 1a presents the emission spectrum of the gas-liquid interface, which confirmed that the formed reducing species ${ }^{\circ} \mathrm{H}$ showed a characteristic emission at $658.8 \mathrm{~nm}$. The discharge gas Ar produces long-lived metastable Ar (3p) species, which transfer the energy to water molecules, leading to the formation of ${ }^{\circ} \mathrm{H}$ and ${ }^{\circ} \mathrm{OH} \cdot{ }^{29,30}$ Goodman's method was used to identify the hydrated electrons $\left(\mathrm{e}_{\mathrm{aq}}{ }^{-}\right)$during plasma discharge. As presented in eqn (4), the hydrated electrons react with ${ }^{\circ} \mathrm{Cl}$ to form $\mathrm{Cl}^{-}$, which was further confirmed by IC (Fig. 1b).

$$
\begin{gathered}
\mathrm{H}_{2} \mathrm{O}^{+}+n \mathrm{H}_{2} \mathrm{O} \rightarrow \mathrm{H}_{3} \mathrm{O}^{+}+n^{\cdot} \mathrm{OH}+(n-1)^{\cdot} \mathrm{H} \\
\mathrm{H}_{2} \mathrm{O}+{ }^{*} \mathrm{e}^{-} \rightarrow \cdot \mathrm{H}+\cdot \mathrm{OH}+\mathrm{e}^{-} \\
\mathrm{H}_{2} \mathrm{O}^{*} \rightarrow{ }^{\cdot} \mathrm{OH}+\mathrm{H}^{+}+\mathrm{e}^{-} \\
\mathrm{e}_{\mathrm{aq}}{ }^{-}+\mathrm{ClCH}_{2} \mathrm{COOH} \rightarrow \mathrm{Cl}^{-}+{ }^{\cdot} \mathrm{CH}_{2} \mathrm{COOH}
\end{gathered}
$$

The highly energetic electrons can induce the dissociation of water molecules to ${ }^{\circ} \mathrm{OH}$ and ${ }^{\circ} \mathrm{H}$ in an aqueous solution (eqn (1)-

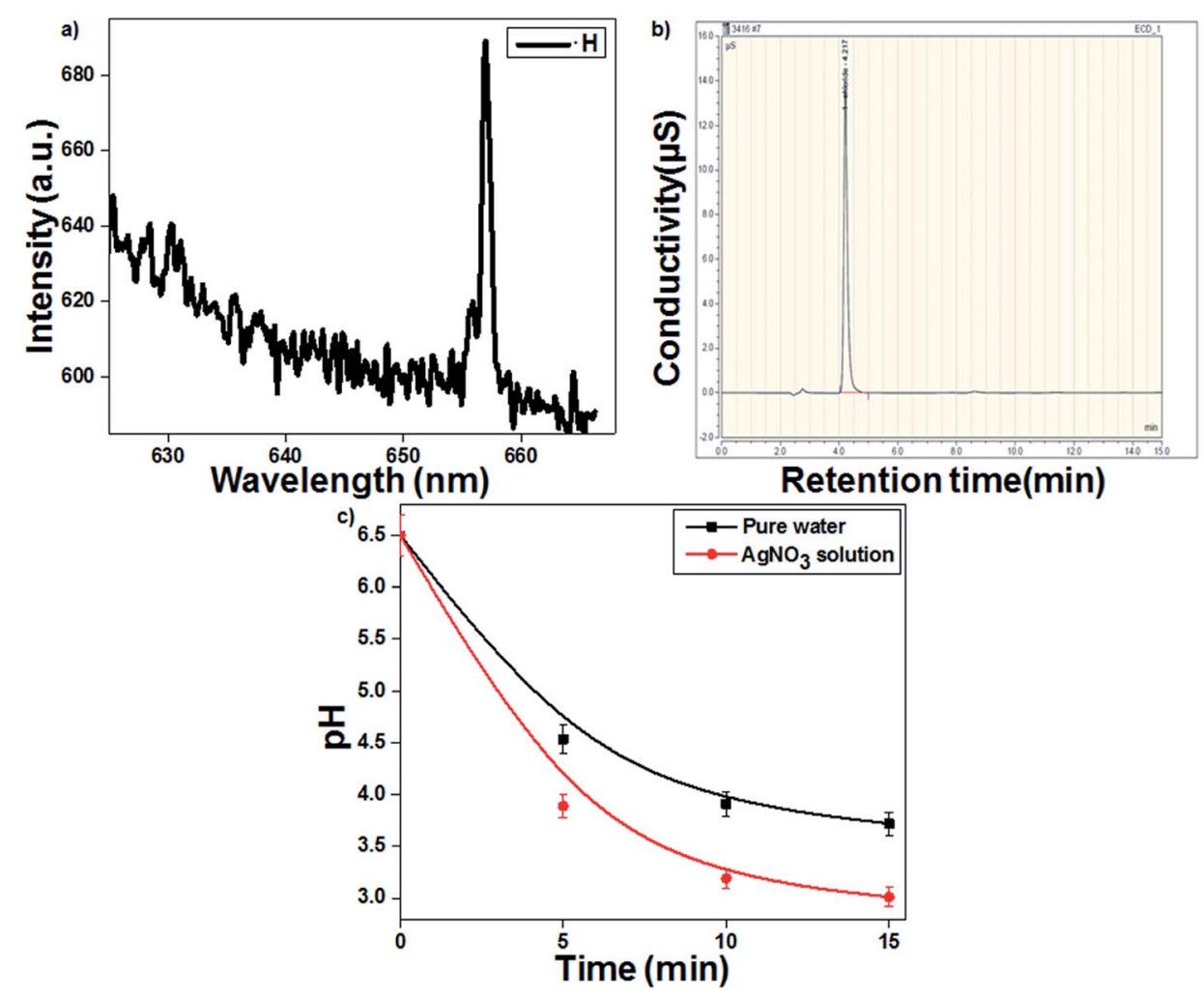

Fig. 1 (a) Optical emission spectrum of the hydrogen radical ( $\left.{ }^{*} H\right)$. (b) Chromatogram of chloride ions. (c) Change in solution pH as a function of treatment time (16 kV voltage and $300 \mathrm{sccm}$ Ar gas flow). 
(3)). Additionally, the strong reducing species $\mathrm{e}_{\mathrm{aq}}{ }^{-}$and ${ }^{\circ} \mathrm{H}$ from the plasma discharge can easily reduce $\mathrm{Ag}^{+}$metal ions into $\mathrm{Ag}$ colloidal solution (eqn (5) and (6)). ${ }^{31}$ The highly energetic electrons play a prominent role in protecting the plasma-reduced colloidal $\mathrm{Ag}$ nanoparticles from aggregation. ${ }^{22}$ The particles retain their electric charge and repel each other, resulting in the formation of stable and uniform colloidal AgNPs. The time required for $\mathrm{Ag}^{+}$ion reduction decreased to $10 \mathrm{~min}$ in the presence of the ${ }^{\circ} \mathrm{OH}$ scavenger TA, which prevented the recombination of ${ }^{\circ} \mathrm{H}$ and ${ }^{\circ} \mathrm{OH}$. The $\mathrm{pH}$ of the $\mathrm{AgNO}_{3}$ solution decreased more than that of the blank (pure water). As presented in eqn (6), the reduction of $\mathrm{Ag}^{+}$by plasma was accompanied with the release of a proton. Therefore, the $\mathrm{AgNO}_{3}$ containing solution became more acidic (3.01) than the blank solution (3.72) (Fig. 1c).

$$
\begin{gathered}
\mathrm{Ag}^{+}+\mathrm{e}_{\mathrm{aq}}^{-} \rightarrow \mathrm{Ag} k=3.3 \times 10^{10} \\
\mathrm{Ag}^{+}+{ }^{\cdot} \mathrm{H} \rightarrow \mathrm{Ag}+\mathrm{H}^{+} k=2.2 \times 10^{10}
\end{gathered}
$$

\subsection{Ultraviolet-visible and fluorescence spectroscopy}

UV-Vis spectroscopy is a preliminary characterization technique, and the formation of AgNPs was confirmed by specific surface plasmon resonance (SPR) bands. ${ }^{32,33}$ The particle size, concentration and shape of the nanoparticles are the most important factors that cause changes in the SPR bands. The effect of the initial concentration of $\mathrm{AgNO}_{3}$ samples was studied by recording their UV-Vis spectrum every $5 \mathrm{~min}$. As seen from Fig. 2a, the synthesis of AgNPs using $1 \mathrm{mM}$ of $\mathrm{AgNO}_{3}$ solution resulted in an SPR peak at $412 \mathrm{~nm}$, which shifted to $421 \mathrm{~nm}$ and $423 \mathrm{~nm}$ with an increase in the $\mathrm{AgNO}_{3}$ concentration from 2 to $3 \mathrm{mM}$, respectively. A red shift and broadening of the SPR peaks were observed with the increase in concentration, which suggested an increase in particle size. The plasma treatment time enhanced the rate of $\mathrm{Ag}^{+}$reduction, and the intensity and sharpness of the SPR peaks increased due to the formation of more AgNPs (Fig. 2b). The UV-Vis spectra of pure $\mathrm{TiO}_{2}$ and $1 \mathrm{wt} \% \mathrm{Ag}$-loaded $\mathrm{TiO}_{2}$ are presented in Fig. S1 in the ESI. $\dagger$ The cut-off wavelength of pure $\mathrm{TiO}_{2}$ was observed at $382 \mathrm{~nm}(3.24$ $\mathrm{eV})$, which shifted to $425(2.91 \mathrm{eV}) \mathrm{nm}$ for the $1 \mathrm{wt} \%$ Ag-loaded $\mathrm{TiO}_{2}$.

The plasma treatment time and the initial concentration of $\mathrm{AgNO}_{3}$ play prominent roles in the synthesis of colloidal AgNPs. In this context, the optimized conditions required to obtain small-sized colloidal AgNPs are $1 \mathrm{mM} \mathrm{AgNO}_{3}$ solution and $15 \mathrm{~min}$ of plasma treatment. The AgNPs prepared with $1 \mathrm{mM} \mathrm{AgNO}_{3}$ via the chemical route with the $\mathrm{NaBH}_{4}$ reducing agent were unstable; after $12 \mathrm{~h}$, a turbid solution was obtained due to the agglomeration of silver nanoparticles. Interestingly, the AgNPs prepared from the plasma approach were stable even after 30 days. As seen from Fig. $2 c$ and d, the absorption spectrum of the chemically reduced AgNPs shifted irregularly, whereas in the spectrum of the plasma-treated AgNPs, this shift was not observed.
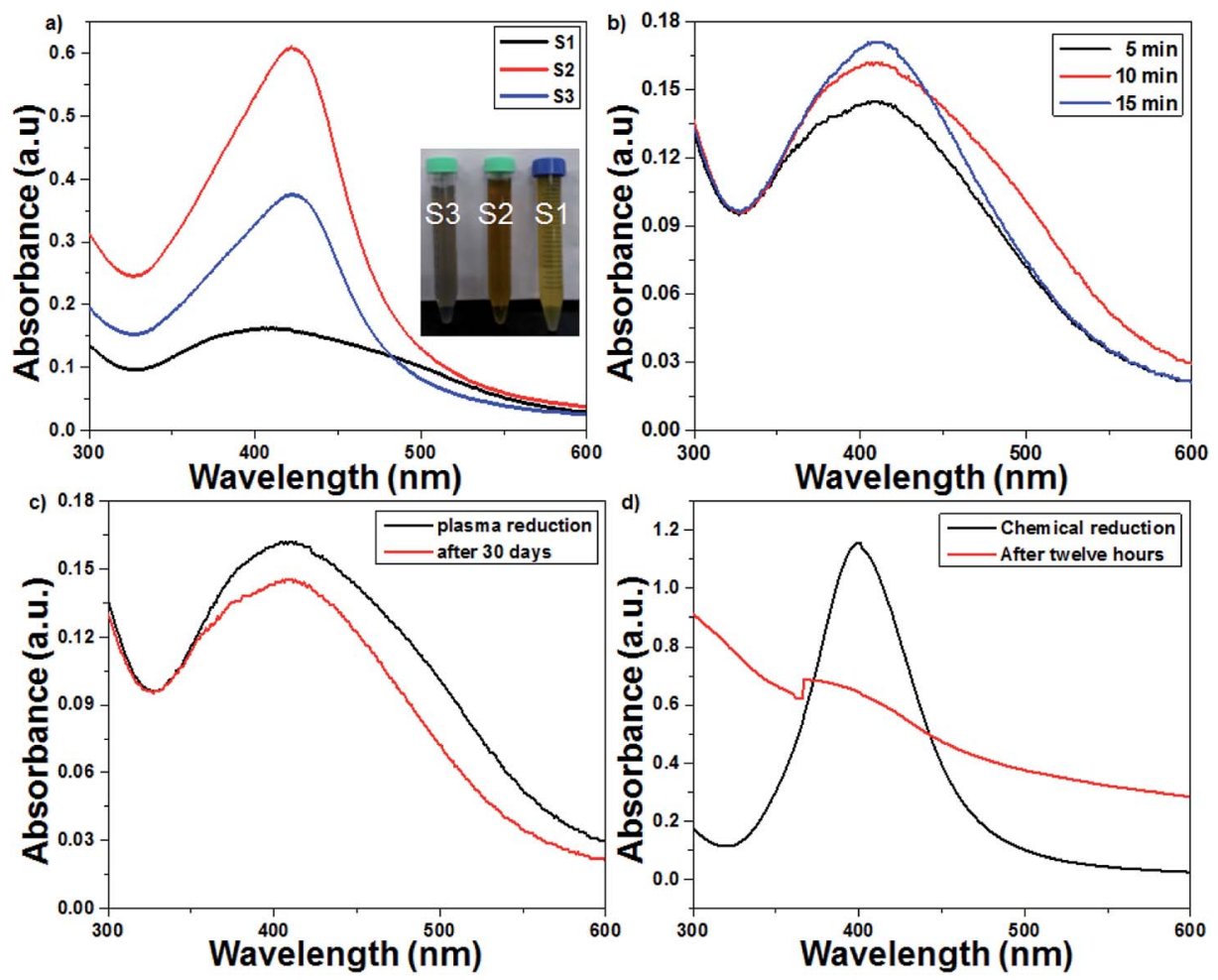

Fig. 2 UV-Vis spectra of the plasma-reduced AgNPs. (a) Effect of the initial concentration (1-3 mM) of $\mathrm{AgNO}_{3}$ solution on the SPR pattern. (b) Effect of the plasma treatment time on the SPR pattern (at $16 \mathrm{kV}$ voltage and $300 \mathrm{sccm}$ Ar gas flow). (c) Plasma-reduced AgNPs immediately and 30 days after their preparation. (d) Chemically reduced AgNPs immediately and $12 \mathrm{~h}$ after their preparation. 


\section{$3.3 \quad$ XRD}

The X-ray diffraction patterns of the plasma-reduced silver nanoparticles are shown in Fig. 3. The strong Bragg reflections at the $2 \theta$ values of $38.26^{\circ}(2.35), 44.21^{\circ}(2.05), 64.52^{\circ}(1.44), 77.55^{\circ}(1.23)$ and $81.68^{\circ}$ (1.18) corresponded to the (111), (200) (220) (311) and (222) planes, which confirmed the formation of Ag nanoparticles (JCPDS file no. 04-0783). ${ }^{34}$ As seen from the above-mentioned patterns, the most significant peak was positioned at a $d$-spacing of $2.35 \mathrm{~A}^{\circ}$, which corresponded to the (111) plane. In addition, the crystal sizes of these AgNPs were calculated using the Debye-Scherrer formula, as given in eqn (7), and they were found to be 11, 14 and $16 \mathrm{~nm}$. The XRD results confirmed that the resultant silver particles were crystalized in an FCC arrangement. The XRD pattern of $\mathrm{TiO}_{2}$ and $\mathrm{Ag}$-loaded $\mathrm{TiO}_{2}$ is given in Fig. S2 in ESI. $\dagger$ It was noted that no Ag phase was identified by XRD analysis since the content of $\mathrm{Ag}$ loaded on the $\mathrm{TiO}_{2}$ surface was very low.

$$
d=K \lambda / \beta \cos \theta
$$

\subsection{TEM}

The TEM images of AgNPs are presented in Fig. 4a-c, which show highly dispersed and spherical colloidal nanoparticles. The average particle sizes of AgNPs are around 11, 14 and $16 \mathrm{~nm}$ for $1 \mathrm{mM}, 2 \mathrm{mM}$ and $3 \mathrm{mM}$ samples, respectively. The selected area electron diffraction (inset of Fig. 4) confirms the interlayer spacing of $0.236 \mathrm{~nm}$, which is the characteristic $d$-spacing for the (111) plane of $\mathrm{Ag}$, and this result is consistent with the observation made from the XRD data. The particle size increases with an increase in the initial concentration, as shown in Fig. $4 \mathrm{~d}-\mathrm{f}$.

\subsection{Antibacterial activity of plasma- and chemically reduced AgNPs}

The plasma-reduced AgNPs (S1, S2 and S3) were tested for their antibacterial activities on E. coli. In this study, E. coli with a CFU

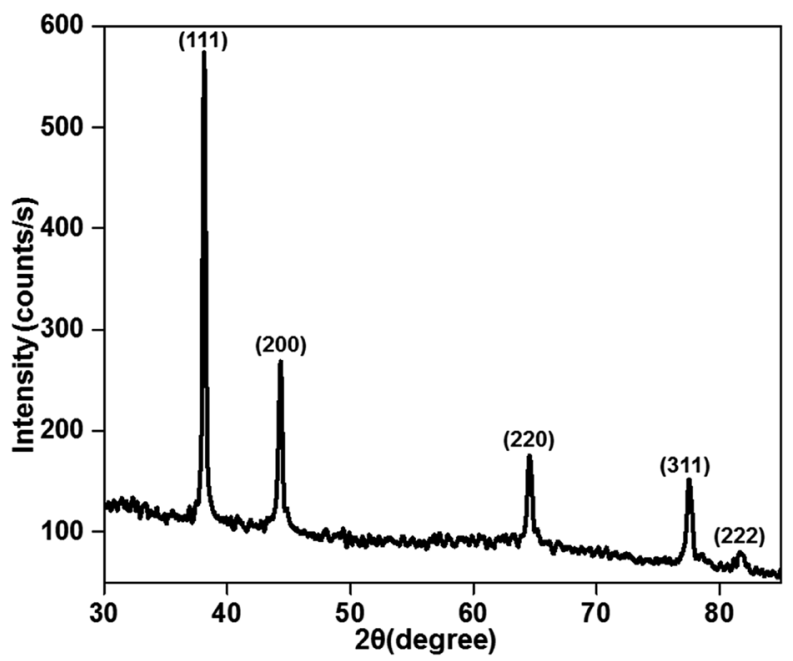

Fig. 3 X-ray diffraction pattern of the plasma-reduced silver nanoparticles (at $16 \mathrm{kV}$ voltage and $300 \mathrm{sccm}$ Ar gas flow). concentration of $10^{7}$ per $\mathrm{mL}$ was used to study the antibacterial activity of AgNPs (inset of Fig. 5). The bacterial (E. coli) growth curves decreased with a decrease in the particle size and accordingly, S1 showed the highest antibacterial activity due to their smallest particle size (Fig. 5a). The antibacterial activity of AgNPs was collectively due to the ROS formation as well as $\mathrm{Ag}^{+}$ions. S1 showed the highest amount of ROS ( $\left.{ }^{\circ} \mathrm{OH}\right)$ than $\mathrm{S} 3$, which indicated that AgNPs having small particle size showed the highest amount of ROS formation (Fig. S3 in ESI $\dagger$ ). Additionally, the effect of $\mathrm{Ag}^{+}$ ions was also studied. An equivalent amount of $\mathrm{Ag}$ salt was added to the bacterial solution, and only $64 \%$ bacterial inactivation was observed; this indicated that for bacterial inactivation, both AgNPs and $\mathrm{Ag}^{+}$ions play important roles (Fig. $\mathrm{S} 4$ in ESI $\dagger$ ).

Since the above-mentioned studies confirmed that sample S1 showed the best antibacterial activity, further experiments were continued with the same sample. The minimum inhibitory concentration (MIC) method was used to study the antibacterial effectiveness with different AgNP concentrations. AgNPs with concentrations ranging from 10 to $50 \mathrm{mg} \mathrm{L}^{-1}$ were added to the bacterial culture and then incubated for $12 \mathrm{~h}$ at $37{ }^{\circ} \mathrm{C}$ with a constant stirring rate of $200 \mathrm{rpm}$. The final bacterial concentration decreased with an increase in the AgNP concentration; when the concentration reached $40 \mathrm{mg} \mathrm{L}^{-1}, E$. coli growth was completely inhibited. In the present study, MIC of AgNPs to E. coli was $40 \mathrm{mg} \mathrm{L}^{-1}$ (Fig. 5b). To study the bacterial growth curve, the bacterial (E. coli) concentration was monitored every $1 \mathrm{~h}$ by optical density (OD) at $600 \mathrm{~nm}$ (Fig. 5c). It was found that the bacterial growth decreased continuously with an increase in the AgNP concentration. At a low concentration of AgNPs, bacterial growth was delayed; however, at a higher concentration, bacterial growth was completely inhibited. When the activity of plasma-reduced AgNPs was compared with that of the chemically reduced AgNPs, it was confirmed that the activity of $\mathrm{Ag}$-P was better than that of Ag-C. The antimicrobial activity of AgNPs was investigated by many scientists against a broad range of microbes including bacteria, viruses and fungi. Nowadays, AgNPs are a well-established alternative to antibiotic therapy because of their significant potential for solving the problems associated with the development of multidrug resistance in microorganisms and hence, they are known as next-generation antibiotics. ${ }^{35,36}$

\subsection{Photocatalytic activity of plasma- and chemically reduced AgNPs}

The photocatalytic degradation of CV was studied with $\mathrm{TiO}_{2}$ and Ag-supported $\mathrm{TiO}_{2}$ catalysts $\left(0.5 \mathrm{wt} \% \mathrm{Ag}(\mathrm{P})-\mathrm{TiO}_{2}, 1 \mathrm{wt} \% \mathrm{Ag}(\mathrm{P})-\right.$ $\mathrm{TiO}_{2}, 2 \mathrm{wt} \% \mathrm{Ag}(\mathrm{P})-\mathrm{TiO}_{2}$ and $\left.1 \mathrm{wt} \% \mathrm{Ag}(\mathrm{C})-\mathrm{TiO}_{2}\right)$ with the optimum concentration of $1 \mathrm{~g} \mathrm{~L}^{-1} ; 1 \mathrm{wt} \% \mathrm{Ag}(\mathrm{P})-\mathrm{TiO}_{2}$ showed the best conversion (98\%) (Fig. 6a). In the case of $2 \mathrm{wt} \% \mathrm{Ag}-$ $\mathrm{TiO}_{2}$, an excess amount of $\mathrm{Ag}$ occupied more $\mathrm{TiO}_{2}$ surface and lowered the possibility of contact with $\mathrm{O}_{2},{ }^{14}$ which may inhibit the electron transfer from $\mathrm{TiO}_{2}$ to $\mathrm{O}_{2}$ molecules, resulting in the decrease in catalytic activity. The degradation of organic dye followed first-order kinetics, and the rate constants (eqn (8)) were found to be $0.03,0.025,0.02,0.007$ and $0.005 \mathrm{~min}^{-1}$ for 



Fig. 4 (a-c) TEM images of the colloidal Ag nanoparticles (scale bar: $50 \mathrm{~nm}$ ) and $(\mathrm{d}-\mathrm{f}$ ) size distributions of colloidal Ag nanoparticles (at $16 \mathrm{kV}$ voltage and $300 \mathrm{sccm}$ Ar gas flow).

1 wt $\% \mathrm{Ag}(\mathrm{P})-\mathrm{TiO}_{2}, 2$ wt $\% \mathrm{Ag}(\mathrm{P})-\mathrm{TiO}_{2}, 0.5 \mathrm{wt} \% \mathrm{Ag}(\mathrm{P})-\mathrm{TiO}_{2}, 1$ wt $\%$ $\mathrm{Ag}(\mathrm{C})-\mathrm{TiO}_{2}$ and pure $\mathrm{TiO}_{2}$ (Fig. 6b), respectively.

$$
-\ln \left(C_{\mathrm{t}} / C_{0}\right)=k t
$$

Since the results confirmed that $1 \mathrm{wt} \% \mathrm{Ag}(\mathrm{P})-\mathrm{TiO}_{2}$ catalyst showed the best photocatalytic activity, it was used for further experiments. A set of experiments were carried out by varying the catalyst ( $1 \mathrm{wt} \% \mathrm{Ag}-\mathrm{TiO}_{2}$ ) amount in the range of $30-60 \mathrm{mg}$; the activity data indicated that an increase in conversion was achieved with an increase in the catalyst concentration up to $1 \mathrm{~g}$ $\mathrm{L}^{-1}$ and after that, the efficiency decreased (Fig. 6c). This can be explained in terms of active sites present on the catalyst surface for the photocatalytic reactions. A high amount of catalyst in solution increases the turbidity, which may decrease the interaction of light with the active sites present on the catalyst
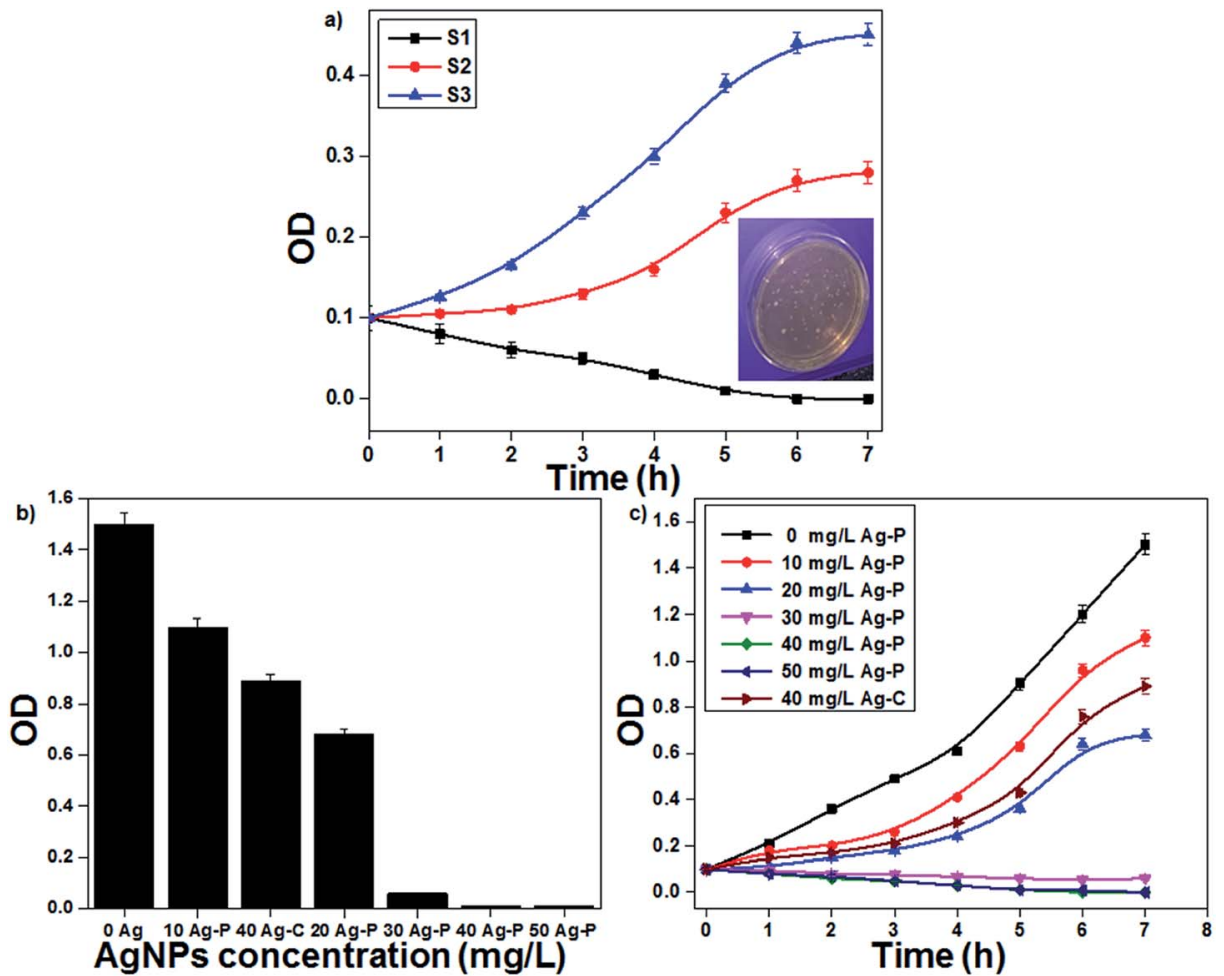

Fig. 5 (a) Growth curves of E. coli with AgNPs having different particle sizes. (b) MIC assay of the plasma-reduced AgNPs. (c) The effect of the concentration of AgNPs on E. coli growth curves (initial OD at 0.1). 

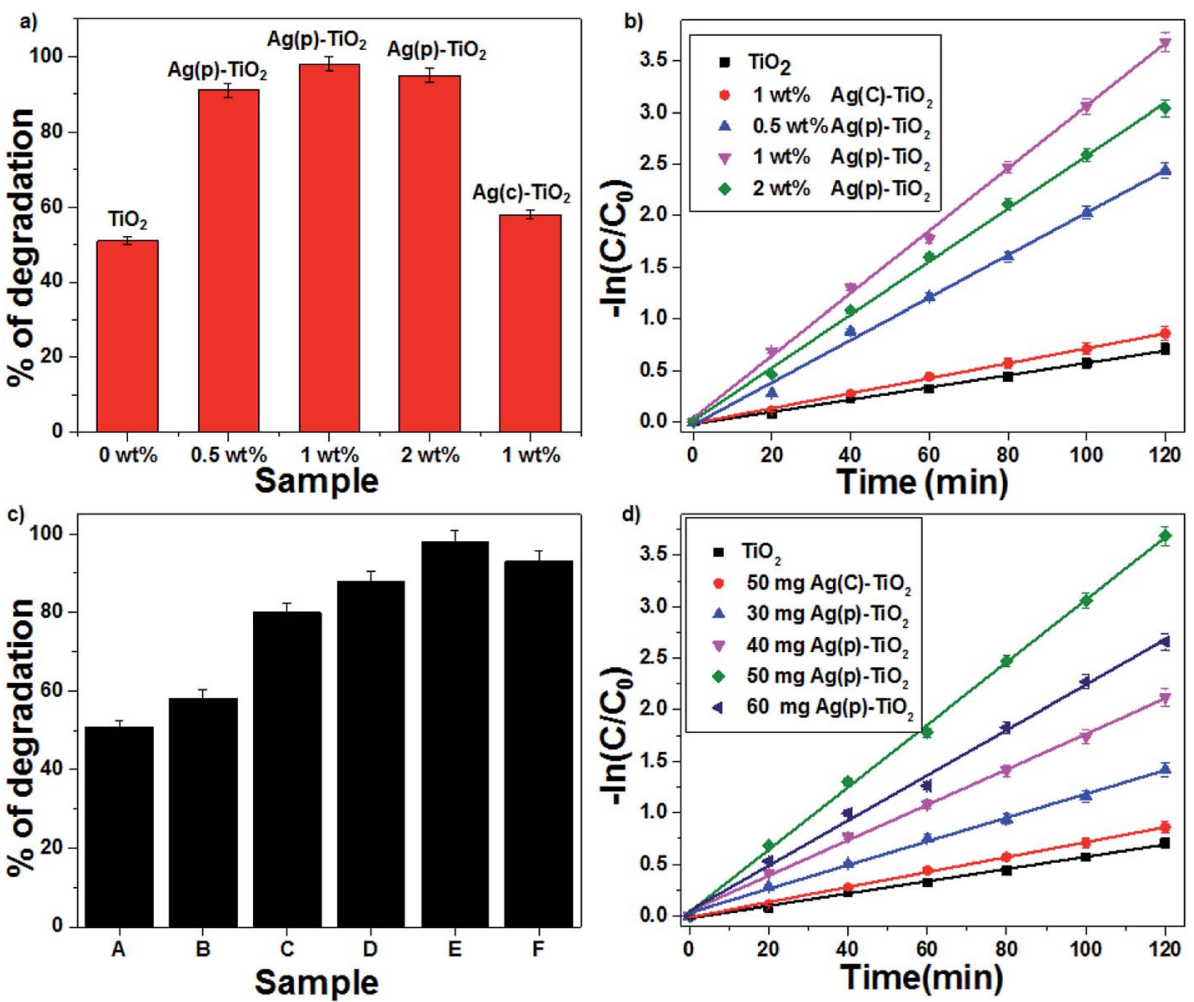

Fig. 6 The effect of the Ag-supported $\mathrm{TiO}_{2}$ catalyst on CV degradation: (a) \% of degradation and (b) first-order kinetic plots. The effect of the amount of $1 \mathrm{wt} \% \mathrm{Ag}-\mathrm{TiO}_{2}$ catalyst on $\mathrm{CV}$ degradation: (c) \% degradation (d) first order kinetic plots ((A) $\mathrm{TiO}_{2},(\mathrm{~B}) 50 \mathrm{mg} \mathrm{Ag}(\mathrm{C})-\mathrm{TiO}$, (C) $30 \mathrm{mg}$ $\mathrm{Ag}(\mathrm{P})-\mathrm{TiO}_{2}$, (D) $40 \mathrm{mg} \mathrm{Ag}(\mathrm{P})-\mathrm{TiO}_{2}$, (E) $50 \mathrm{mg} \mathrm{Ag}(\mathrm{P})-\mathrm{TiO}_{2}$, and (F) $60 \mathrm{mg} \mathrm{Ag}(\mathrm{P})-\mathrm{TiO}_{2}$ ).

surface. The maximum degradation of $\mathrm{CV}$ was observed with $1 \mathrm{wt} \% \mathrm{Ag}(\mathrm{P})-\mathrm{TiO}_{2}$ at $1 \mathrm{~g} \mathrm{~L}^{-1}$ within 120 min under sunlight. As seen from Fig. 6d, the degradation of $\mathrm{CV}$ followed first-order kinetics, and the rate constants were found to be $0.005,0.007$, 0.0116, 0.017, 0.022 and $0.03 \mathrm{~min}^{-1}$ for pure $\mathrm{TiO}_{2}, 50 \mathrm{mg} \mathrm{Ag}(\mathrm{C})-$ $\mathrm{TiO}_{2}, 30 \mathrm{mg} \mathrm{Ag}(\mathrm{P})-\mathrm{TiO}_{2}, 40 \mathrm{mg} \mathrm{Ag}(\mathrm{P})-\mathrm{TiO}_{2}, 60 \mathrm{mg} \mathrm{Ag}(\mathrm{P})-\mathrm{TiO}_{2}$, and $50 \mathrm{mg} \mathrm{Ag}(\mathrm{P})-\mathrm{TiO}_{2}$, respectively. The effect of $1 \mathrm{wt} \% \mathrm{Ag}(\mathrm{P})-$ $\mathrm{TiO}_{2}$ catalyst loading on the degradation of $\mathrm{CV}$ highlighted the better performance of the plasma-reduced $\mathrm{Ag}-\mathrm{P}$ catalyst than that of chemically reduced $\mathrm{Ag}-\mathrm{C}$ with the same amount of the catalyst. A plausible mechanism for the degradation of $\mathrm{CV}$ is shown in Fig. S5 in the ESI. $\dagger$ The degradation of CV dye may occur through the attack of ${ }^{\circ} \mathrm{OH}$ on the central carbon of $\mathrm{CV}$ via the conjugated structure of aminotriphenylmethane to produce intermediates, which are further oxidized to $\mathrm{CO}_{2}$ and $\mathrm{H}_{2} \mathrm{O}$ (mineralization products). ${ }^{37}$ The extent of mineralization was achieved up to $56 \%$ with the highly active $1 \mathrm{wt} \% \mathrm{Ag}(\mathrm{P})-\mathrm{TiO}_{2}$ catalyst, and it also showed the best conversion (98\%), which decreased to $61 \%$ in the presence of isopropyl alcohol (hydroxyl scavenger). The complete degradation of $\mathrm{CV}$ was achieved within $70 \mathrm{~min}$ in the presence of $\mathrm{FeCl}_{2}$, which may be due to the formation of ${ }^{\circ} \mathrm{OH}$ via Fenton reactions, which readily oxidizes CV (eqn (9))

$$
\mathrm{Fe}^{2+}+\mathrm{H}_{2} \mathrm{O}_{2} \rightarrow \cdot \mathrm{OH}+\mathrm{OH}^{-}+\mathrm{Fe}^{3+}
$$

$\mathrm{TiO}_{2}$ is a proven photocatalyst, which has a wide band gap of $3.2 \mathrm{eV}$. Accordingly, the modification of $\mathrm{TiO}_{2}$ with noble metal nanoparticles such as $\mathrm{Ag}$ or $\mathrm{Au}$ shifts its absorption edge to the visible region $(<3.2 \mathrm{eV})$. Since the experiments are conducted with commercial $\mathrm{TiO}_{2}$ under open sunlight, the observed activity is explained based on the combined effect of $\mathrm{TiO}_{2}$ and AgNPs impregnated on $\mathrm{TiO}_{2}$. During the photo-excitation of AgNPs under sunlight, the electrons below the Fermi level $\left(E_{\mathrm{f}}\right)$ of AgNPs are excited to the surface plasmon states, leaving positive charges $\left(\mathrm{h}^{+}\right)$below $E_{\mathrm{f}}{ }^{38-40}$ The interaction of holes with water molecules leads to the formation of ${ }^{\circ} \mathrm{OH}$ (eqn (10) and (11)). The electrons are transferred to the conduction band of $\mathrm{TiO}_{2}$, which minimizes electron-hole recombination (eqn (12)) and provides more electrons for the reduction of molecular oxygen to superoxide anion radicals $\left({ }^{\circ} \mathrm{O}_{2}{ }^{-}\right)$, the protonation of which gives ${ }^{\circ} \mathrm{HO}_{2}$ radicals (eqn (13) and (14)). The reduction of ${ }^{\circ} \mathrm{HO}_{2}$ yields $\mathrm{H}_{2} \mathrm{O}_{2}$ species, which undergo decomposition to form ${ }^{\circ} \mathrm{OH}$ radicals (eqn (15) and (16)) (Fig. 7). ${ }^{41}$ The ${ }^{\circ} \mathrm{OH}$ radical has an oxidation potential of $2.8 \mathrm{~V}$, which is sufficient to oxidize a wide

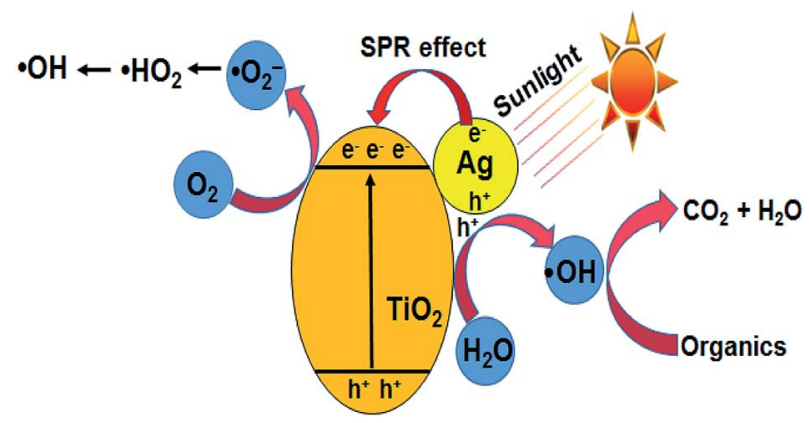

Fig. 7 Schematic diagram of the photocatalytic mechanism of the $\mathrm{Ag}-\mathrm{TiO}_{2}$ catalyst. 



Fig. 8 Identification of reactive oxygen species with $1 \mathrm{wt} \% \mathrm{Ag}(\mathrm{P})-\mathrm{TiO}_{2}$ catalyst: (a) $\mathrm{H}_{2} \mathrm{O}_{2}$ and (b) ${ }^{\circ} \mathrm{OH}$.

range of organic compounds including CV (eqn (17)). The photocatalytic activity of pure $\mathrm{Ag}(\mathrm{P})$ or $\mathrm{Ag}(\mathrm{C})$ is negligible due to rapid electron-hole recombination.

$$
\begin{gathered}
\mathrm{Ag}+h v \rightarrow \mathrm{h}^{+}+\mathrm{e}^{-} \\
\mathrm{h}^{+}+\mathrm{H}_{2} \mathrm{O} \rightarrow \cdot \mathrm{OH}+\mathrm{H}^{+} \\
\mathrm{e}^{-}+\mathrm{TiO}_{2} \rightarrow \mathrm{TiO}_{2}\left(\mathrm{e}^{-}\right) \\
\mathrm{TiO}_{2}\left(\mathrm{e}^{-}\right)+\mathrm{O}_{2} \rightarrow \mathrm{TiO}_{2}+\mathrm{O}_{2}^{-} \\
\mathrm{O}_{2}^{-}+\mathrm{H}^{+} \rightarrow{ }^{\cdot} \mathrm{HO}_{2} \\
\mathrm{HO}_{2}+{ }^{\cdot} \mathrm{HO}_{2} \rightarrow \mathrm{H}_{2} \mathrm{O}_{2}+\mathrm{O}_{2} \\
\mathrm{H}_{2} \mathrm{O}_{2} \rightarrow \cdot \mathrm{OH}+{ }^{\cdot} \mathrm{OH} \\
\cdot \mathrm{OH}+\mathrm{CV} \rightarrow \text { degraded products }
\end{gathered}
$$

\subsection{Identification of reactive oxygen species}

The ROS such as $\mathrm{H}_{2} \mathrm{O}_{2}$ and ${ }^{\circ} \mathrm{OH}$ formed during photocatalysis were identified using the titanium sulfate and chemical dosimetry method. The reactive oxygen species were identified in a solution containing $50 \mathrm{mg}$ of catalyst $\left(1 \mathrm{wt} \% \mathrm{Ag}(\mathrm{P})-\mathrm{TiO}_{2}\right)$ and in the absence of $\mathrm{CV}$ dye. $\mathrm{H}_{2} \mathrm{O}_{2}$ reacted with titanium sulfate to give yellow-colored pertitanic acid, which showed a maximum absorbance at $420 \mathrm{~nm}$, as shown in Fig. $8 \mathrm{a}$. The ${ }^{\circ} \mathrm{OH}$ radicals formed during photocatalysis may react with TA to form HTA, which showed an emission at $425 \mathrm{~nm}$ (Fig. 8b). ${ }^{23}$ The formation of active species was also compared with that of the chemically reduced catalyst $1 \mathrm{wt} \% \mathrm{Ag}(\mathrm{C})-\mathrm{TiO}_{2}$, and the plasmareduced catalyst $1 \mathrm{wt} \% \mathrm{Ag}(\mathrm{P})-\mathrm{TiO}_{2}$ showed the highest active species formation.

\section{Conclusions}

Highly dispersed colloidal silver nanoparticles (AgNPs) were synthesized using an atmospheric pressure plasma jet under ambient conditions. Reducing species such as ${ }^{\circ} \mathrm{H}$ and $\mathrm{e}_{\mathrm{aq}}{ }^{-}$were identified via optical emission spectroscopy (OES) and Goodman's method. It was observed that the $\mathrm{pH}$ of the $\mathrm{AgNO}_{3}$-containing solution decreased during the plasma treatment, which indicated the reduction of $\mathrm{Ag}^{+}$ions. The formation of colloidal AgNPs was confirmed by surface plasmon resonance (SPR) bands using ultraviolet-visible and fluorescence spectroscopies, and TEM images confirmed the spherical morphology of the plasma-reduced Ag nanoparticles. The size of the colloidal AgNPs was tuned by adjusting the $\mathrm{AgNO}_{3}$ initial concentration. The addition of ${ }^{\circ} \mathrm{OH}$ scavenger TA to the solution decreased the treatment time for $\mathrm{Ag}^{+}$reduction. The typical activity tests confirmed that the plasma-reduced AgNPs (Ag-P) showed superior antibacterial and photocatalytic activities than the chemically reduced AgNPs (Ag-C). Interestingly the plasmareduced AgNPs were stable even after 30 days, whereas the chemically reduced AgNPs agglomerated within $12 \mathrm{~h}$. The extent of mineralization achieved was up to $56 \%$ with the highly active $1 \mathrm{wt} \% \mathrm{Ag}(\mathrm{P})-\mathrm{TiO}_{2}$ catalyst. The hydroxyl scavenger isopropyl alcohol showed a negative effect on $\mathrm{CV}$ degradation, whereas $\mathrm{Fe}^{2+}$ salts played a positive role in $\mathrm{CV}$ degradation.

\section{Conflicts of interest}

There are no conflicts to declare.

\section{Acknowledgements}

Authors would like to thank MHRD, India for the financial assistance.

\section{References}

1 K. M. A. El-Nour, A. A. Eftaiha, A. Al-Warthan and R. A. Ammar, Arabian J. Chem., 2010, 3, 135-140.

2 H. Gu, P. L. Ho, E. Tong, L. Wang and B. Xu, Nano Lett., 2003, 3, 1261-1263.

3 J. M. Köhler, L. Abahmane, J. Wagner, J. Albert and G. Mayer, Chem. Eng. Sci., 2008, 63, 5048-5055.

4 M. De, P. S. Ghosh and V. M. Rotello, Adv. Mater., 2008, 20, 4225-4241. 
5 A. A. Kajani, A. K. Bordbar, S. H. Z. Esfahani, A. R. Khosropour and A. Razmjou, $R S C A d v$., 2014, 4, 61394-61403.

6 Q. H. Tran and A. T. Le, Adv. Nat. Sci.: Nanosci. Nanotechnol., 2013, 4, 033001.

7 T. V. Duncan, J. Colloid Interface Sci., 2011, 363, 1-24.

8 Y. Cai, X. Piao, W. Gao, Z. Zhang, E. Nie and Z. Sun, RSC Adv., 2017, 7, 34041-34048.

9 A. Panáček, M. Kolář, R. Večeřová, R. Prucek, J. Soukupová, V. Kryštof and L. Kvítek, Biomaterials, 2009, 30, 6333-6340.

10 S. Chernousova and M. Epple, Angew. Chem., Int. Ed., 2013, 52, 1636-1653.

11 J. Y. Kim, S. E. Kim, J. E. Kim, J. C. Lee and J. Y. Yoon, J. Korean Soc. Environ. Eng., 2005, 27, 771-776.

12 F. Gao, Y. Yang and T. Wang, Chem. Eng. J., 2015, 270, 418427.

13 R. Kaur and B. Pal, New J. Chem., 2015, 39, 5966-5976.

14 Z. Zheng, B. Huang, X. Qin, X. Zhang, Y. Dai and M. H. Whangbo, J. Mater. Chem., 2011, 21, 9079-9087.

15 P. Korshed, L. Li, Z. Liu and T. Wang, PLoS One, 2016, 11, e0160078.

16 Z. Tang, S. Liu, S. Dong and E. Wang, J. Electroanal. Chem., 2001, 502, 146-151.

17 B. Soroushian, I. Lampre, J. Belloni and M. Mostafavi, Radiat. Phys. Chem., 2005, 72, 111-118.

18 M. G. Guzmán, J. Dille and S. Godet, Int. J. Chem. Biol. Eng., 2009, 2, 104-111.

19 T. A. Kareem and A. A. Kaliani, Ionics, 2012, 18, 315-327.

20 N. A. Samoilova, I. V. Blagodatskikh, E. A. Kurskaya, M. A. Krayukhina, O. V. Vyshivannaya, S. S. Abramchuk and I. A. Yamskov, Colloid J., 2013, 75, 409-420.

21 V. G. Pol, H. Grisaru and A. Gedanken, Langmuir, 2005, 21, 3635-3640.

22 X. Liang, Z. J. Wang and C. J. Liu, Nanoscale Res. Lett., 2009, $5,124$.

23 L. Chandana and C. Subrahmanyam, Chem. Eng. J., 2017, 329, 211-219.

24 J. He, I. Ichinose, T. Kunitake and A. Nakao, Langmuir, 2002, 18, 10005-10010.
25 S. S. Kim, H. Lee, B. K. Na and H. K. Song, Catal. Today, 2004, 89, 193-200.

26 L. Chandana, P. M. K. Reddy and C. Subrahmanyam, Chem. Eng. J., 2015, 282, 116-122.

27 D. Ray and C. Subrahmanyam, RSC Adv., 2016, 6, 3949239499.

28 L. Mulfinger, S. D. Solomon, M. Bahadory, A. V. Jeyarajasingam, S. A. Rutkowsky and C. Boritz, J. Chem. Educ., 2007, 84, 322.

29 L. Chandana and C. Subrahmanyam, J. Environ. Chem. Eng., 2016, 6, 3780-3786.

30 H. O. L. Li, J. Kang, K. Urashima and N. Saito, J. Inst. Electrostat. Jpn, 2013, 37, 22-27.

31 N. Shirai, S. Uchida and F. Tochikubo, Jpn. J. Appl. Phys., 2014, 53, 046202.

32 F. U. Khan, Y. Chen, N. U. Khan, Z. U. H. Khan, A. U. Khan, A. Ahmad and P. Wan, J. Photochem. Photobiol., B, 2016, 164, 344-351.

33 R. Desai, V. Mankad, S. K. Gupta and P. K. Jha, Nanosci. Nanotechnol. Lett., 2012, 4, 30-34.

34 Y. Sun and Y. Xia, Science, 2002, 298, 2176-2179.

35 M. K. Rai, S. D. Deshmukh, A. P. Ingle and A. K. Gaade, J. Appl. Microbiol., 2012, 112, 841-852.

36 C. Malarkodi, S. Rajeshkumar, K. Paulkumar, G. Gnanajobitha, M. Vanaja and G. Annadurai, Advances in Nano Research, 2013, 1, 83-91.

37 Y. H. B. Liao, J. X. Wang, J. S. Lin, W. H. Chung, W. Y. Lin and C. C. Chen, Catal. Today, 2011, 174, 148-159.

38 K. H. Leong, B. L. Gan, S. Ibrahim and P. Saravanan, Appl. Surf. Sci., 2014, 319, 128-135.

39 M. Z. Ge, C. Y. Cao, S. H. Li, Y. X. Tang, L. N. Wang, N. Qi and Y. K. Lai, Nanoscale, 2016, 8, 5226-5234.

40 H. Wang, X. Yang, J. Zi, M. Zhou, Z. Ye, J. Li and Y. Yan, J. Ind. Eng. Chem., 2016, 35, 83-92.

41 M. Pelaez, N. T. Nolan, S. C. Pillai, M. K. Seery, P. Falaras, A. G. Kontos and M. H. Entezari, Appl. Catal., B, 2012, 125, 331-349. 